DOI: https://doi.org/10.32838/2523-4803/69-4-38

УДК [336.115:005.332.4]:621(045)

\title{
Харчук T.B.
}

кандидат економічних наук, доцент,

ПВНЗ «Свропейський університет»

\section{Kharchuk Tetiana}

European University

\section{МЕТОДИЧНИЙ ПІДХІД ДО ОЦІНЮВАННЯ ФІНАНСОВОЇ СКЛАДОВОЇ КОНКУРЕНТНОГО ПОТЕНЦІАЛУ ПІДПРИЕМСТВ МАШИНОБУДУВАННЯ У СИСТЕМІ ЕКОНОМІЧНОГО УПРАВЛІННЯ}

\begin{abstract}
У статті висвітлено основні етапи застосування методичного підходу до оцінювання фінансової складової конкурентного потенціалу підприємств машинобудування в системі економічного управління. Оиінювання фінансової складової конкурентного потенціалу здійснено за 2008-2017 роки на основі даних фінансової звітності тридияти одного підприємства машинобудування, які за класифікатором видів економічної діяльності віднесено до групи «Виробництво машин і устаткування, не віднесених до інших угрупувань». Визначено еталонні значення формування та використання фінансових ресурсів підприємствами машинобудування за досліджуваний період. Розраховано відстані від еталонного значення, здійснено розподіл підприємств машинобудування за узагальнюючим показником фінансової складової конкурентного потениіалу за рівнями на підставі розробленої шкали формування та використання фінансових ресурсів. Запропонований методичний підхід дасть змогу порівняти реальні та необхідні ресурсні можливості досягнення економічних иілей та виконання завдань підприємства в конкурентному середовищі.

Ключові слова: конкурентоспроможність підприємства, конкурентний потенціал, конкурентні переваги, економічне управління підприсмством, фінансові ресурси, фінансова складова конкурентного потенціалу, підприємства машинобудування.
\end{abstract}

Постановка проблеми. У сучасних умовах господарювання конкурентний потенціал розглядається як один 3 найважливіших об'єктів управління у системі економічного управління підприємством, що «не просто опікується проблематикою управління залученням та використанням окремих видів ресурсів, а концентрує увагу на збалансованості наявних ресурсів, цілеспрямованості формування їхньої системи, створенні умов для оптимального використання наявної системи ресурсів» $[1$, с. 11$]$.

Конкурентний потенціал у системі економічного управління підприємством відображає сукупність економічних ресурсів, компетенцій та можливостей, які вже використовуються або можуть використовуватись як у поточній економічній діяльності, так і в довгостроковій перспективі, а також є основою формування стійких конкурентних переваг. При цьому формування конкурентної переваги щодо інших учасників ринку безпосередньо залежить від ідентифікації стану насамперед фінансової складової конкурентного потенціалу, яка відображає наявність у підприємства можливостей, здатностей, конкурентної сили щодо формування та використання фінансових ресурсів, їх раціонального розподілу та правильної комбінації (з урахуванням впливу факторів зовнішнього середовища), а також створює передумови для підвищення його конкурентоспроможності.
Формування обсягу фінансових ресурсів, достатнього для вирішення завдань економічного управління машинобудівними підприємствами щодо забезпечення їхнього довгострокового стійкого функціонування (життєздатності), потребує розроблення методичного підходу до оцінювання фінансової складової конкурентного потенціалу, що дасть змогу окреслити напрями вдосконалення системи економічного управління підприємством, визначити засоби перетворення наявних фінансових ресурсів на конкурентні переваги та віднайти резерви формування нових ресурсів для забезпечення стійких конкурентних переваг у довгостроковій перспективі.

Аналіз останніх досліджень і публікацій. Широке коло питань, пов'язаних із дослідженням сутності та оцінювання конкурентного потенціалу підприємства, висвітлено в працях таких учених, як О.С. Бабина, Л.В. Балабанова, О.В. Березін, Н.С. Бєляєва, С.В. Близнюк, А.Є. Воронкова, О.Д. Гудзинський, П.В. Забєлін, Н.П. Карачина, І.М. Кирчата, В.В. Лисевич, Я.В. Лісун, О.В. Малик, Т.С. Мельник, Й.М. Петрович, Г.С. Рахімова, І.М. Рєпіна, С.Б. Романишин, О.І. Смагач, Т.В. Смелянець, Р.О. Толпежніков, Х.А. Фасхієв, О.С. Федонін, З.Е. Шершньова, О.Г. Янковий. Попри запропонований досить різноманітний методичний інструментарій щодо оцінювання конкурентного потенціалу підприємства у зарубіжній та вітчизняній економічній науці, актуальним залишається пошук нових, 
удосконалених, сучасних методів, які б не лише дали змогу визначити наявність, розміщення та використання фінансових ресурсів для забезпечення розширеного відтворення на основі перевищення доходів над видатками, але й слугували основою розроблення заходів, спрямованих на досягнення цілей економічного управління підприємством.

Формулювання цілей статті. Мета статті полягає у розробленні методичного підходу до оцінювання фінансової складової конкурентного потенціалу підприємств машинобудування, що дасть змогу порівняти реальні та необхідні ресурсні можливості, спрямовані на реалізацію економічних цілей та завдань підприємства в конкурентному середовищі, а також окреслити напрями вдосконалення системи економічного управління підприємством, визначити засоби перетворення наявних фінансових ресурсів на конкурентні переваги.

Виклад основного матеріалу. Необхідною передумовою розвитку машинобудівних підприємств $\epsilon$ збалансованість фінансових ресурсів, задіяних в економічній діяльності (іх кількісна оцінка грунтується на показниках, які значною мірою відображають наявність та стан фінансових ресурсів), ефективне використання яких дає змогу забезпечувати самофінансування та виробництво конкурентоспроможної продукції як на внутрішньому, так і зовнішньому ринках. Серед різноманіття методик та методів оцінювання фінансової складової конкурентного потенціалу підприємства, на наш погляд, на особливу увагу заслуговує метод таксономії, який дає змогу уникнути необхідності поєднання або моделювання декількох методів і, відповідно, подвійного врахування показників, що, безумовно, підвищить вірогідність отриманих результатів.

Оскільки фінансова складова конкурентного потенціалу формує передумови забезпечення конкурентоспроможності підприємства завдяки вдалому поєднанню фінансових ресурсів і ключових компетенцій для створення унікально привабливих товарів і послуг, які важко скопіювати іншим підприємствам, на наш погляд, доцільно порівняти рівні формування та використання фінансових ресурсів підприємств машинобудування 3 еталонним значенням (максимально можливим), що відповідає значенню 1 (або 100\%) залежно від одиниць виміру, які використовуються під час розрахунку.

Оцінювання фінансової складової конкурентного потенціалу здійснене на основі даних фінансової звітності тридцяти одного підприємства машинобудування, які за класифікатором видів економічної діяльності віднесено до групи «Виробництво машин i устаткування, не віднесених до інших угрупувань», які виробляють машини й устаткування для сільського та лісового господарства, а також виготовлення харчових продуктів і напоїв, перероблення тютюну.

Послідовність застосування методу таксономічного аналізу для оцінювання фінансової складової конкурентного потенціалу підприємств машинобудування, в основу якого покладено сукупність показників, що максимально повно розкривають стан фінансових ресурсів підприємства, представлена у вигляді семи етапів дослідження.
На першому етапі оцінювання для характеристики цілеспрямовано сформованої сукупності фінансових ресурсів у системі економічного управління підприємствами машинобудування за 2008-2017 роки обчислено 23 показники, що характеризують стан акумулювання та використання фінансових ресурсів, а саме показники фінансової стійкості, ліквідності, платоспроможності та ділової активності.

На другому етапі оцінювання фінансової складової конкурентного потенціалу побудовано матриці значень визначених показників:

$$
x=\left[\begin{array}{ccc}
x_{11} & x_{12} & \ldots . x_{1 j} \\
x_{21} & x_{22} & \ldots . x_{2 j} \\
x_{i 1} & x_{i 2} & \ldots . . x_{i j}
\end{array}\right],
$$

де $i$ - порядковий номер досліджуваного об'єкта від 1 до $n ; j$ - порядковий номер досліджуваної ознаки за кожним об'єктом від 1 до $p$.

На третьому етапі оцінювання для проведення подальших розрахунків необхідна стандартизація, яка дає змогу звести всю одиницю виміру до безрозмірної величини, тобто вирівняти значення ознак [2], що передбачає визначення середнього значення за кожним показником:

$$
Z_{i j}=\frac{X_{i j}}{\bar{X}_{j}},
$$

де $Z_{i j}$ - стандартизоване значення $j$ для одиниці $i$; $X_{i j}$ - елементи матриці стандартизованих значень; $\bar{X}_{j}-$ середнє значення.

На четвертому етапі сформовано матрицю відстаней, на підставі якої визначено місце розташування кожного конкретного об'єкта в усій сукупності досліджуваних об’єктів:

$$
C_{i o}=\left|Z_{i j}-Z_{o j}\right|,
$$

де $Z_{i j}$ - значення стандартизованої $j$-ї ознаки для $i$-го об'єкта; $Z_{o j}$ - значення стандартизованої $j$-ї ознаки для об'єкта-бази.

На п'ятому етапі здійснено диференціацію ознак на стимулятори та дестимулятори. Підставою такого поділу є характерний вплив кожного 3 показників на рівень розвитку досліджуваного об'єкта. Ознаки, які надають позитивний (стимулюючий) вплив на загальний рівень розвитку об'єкта, є стимуляторами, а ознаки, що уповільнюють розвиток підприємства, - дестимуляторами. Поділ ознак на стимулятори та дестимулятори $\epsilon$ основою побудови вектору-еталона, який має координати $X_{\text {oi }}$ та формується зі значень таких показників [2]: $Z_{o i}=\max Z_{i j}$, якщо показник ј є стимулятором; $Z_{o i}=\min Z_{i j}$, якщо показник $j \in$ дестимулятором.

На шостому етапі після розподілу ознак на стимулятори та дестимулятори на основі елементів матриці $Z$ сформовано вектор-еталон $\left(P_{o}\right)$ для досліджуваних машинобудівних підприємств. Відстань між точкоюодиницею та точкою $P_{o}$ розраховано за формулою:

$$
C_{i o}=\sqrt{\sum_{j=1}^{m}\left(Z_{i j}-Z_{o j}\right)^{\wedge 2}} .
$$


На сьомому етапі для визначення показника таксономії розраховано середню відстань від об'єкта до еталона, нормовану відстань від об'єкта до еталона для кожного року за формулами:

$$
\begin{gathered}
K_{i}=1-d_{i}, \text { де } d_{i}=\frac{C_{i o}}{C_{o}}, C_{o}=\overline{C_{o}}+2 S_{o}, \\
S_{o}=\sqrt{\frac{1}{m}} \sum_{i=1}^{m}\left(C_{i o}-\overline{C_{o}}\right)^{\wedge 2} .
\end{gathered}
$$

Отримані значення фінансової складової конкурентного потенціалу за всіма досліджуваними підприємствами машинобудування наведені в табл. 1.

Таким чином, серед досліджуваних підприємств машинобудування, еталон показників фінансової складової конкурентного потенціалу у 2008-2009 роках мав значення 0,999 і 0,987 та належав ПАТ «Вібросепаратор», що свідчить про те, що підприємство функціонувало переважно за рахунок власних джерел фінансових ресурсів, а частина залучених коштів за коефіцієнтом фінансування є незначною.

Відстань від еталонного значення фінансової складової конкурентного потенціалу решти підприємств, яке у 2017 році належало ПрАТ «Хорольський механічний завод» $(0,964)$, мала такі показники: ПАТ «Карлівський машинобудівний завод» - 0,662; ПрАТ «Харківпродмаш»- 0,949; ПрАТ «Автоелектроапаратура» - 0,187; ПрАТ «Дніпрополімермаш» - 0,393; ПАТ «Красилівський машинобудівний завод» - 0,941.

Для подальшої інтерпретації зазначених відстаней показників фінансової складової конкурентного потенціалу підприємств машинобудування розроблено шкалу значень узагальнюючого показника рівня формування та використання фінансових ресурсів підприємствами машинобудування з використанням формули Стерджеса, яку наведено на рис. 1.

Таблиця 1

\begin{tabular}{|c|c|c|c|c|c|c|c|c|c|c|}
\hline \multirow{2}{*}{ Підприсмство } & \multicolumn{10}{|c|}{ Рік } \\
\hline & 2008 & 2009 & 2010 & 2011 & 2012 & 2013 & 2014 & 2015 & 2016 & 2017 \\
\hline ПАТ «Карлівський машинобудівний завод» & 0,83 & 0,51 & 0,60 & 0,49 & 0,15 & 0,41 & 0,05 & 0,40 & 0,57 & 0,30 \\
\hline ПрАТ «Харківпродмаш» & 0,90 & 0,68 & 0,65 & 0,28 & 0,32 & 0,23 & 0,31 & 0,21 & 0,12 & 0,02 \\
\hline ПрАТ «Автоелектроапаратура» & 0,77 & 0,78 & 0,26 & 0,68 & 0,66 & 0,48 & 0,66 & 0,79 & 0,87 & 0,78 \\
\hline ПрАТ «Дніпро-полімермаш» & 0,21 & 0,59 & 0,70 & 0,67 & 0,38 & 0,57 & 0,58 & 0,56 & 0,56 & 0,57 \\
\hline ПАТ «Красилівський машинобудів & 0,81 & 0,72 & 0,71 & 0,75 & 0,93 & 0,99 & 0,95 & 0,26 & 0,33 & 0,02 \\
\hline ПрАТ «Ремтехсільмаш» & 0,29 & 0,30 & 0,30 & 0,30 & 0,32 & 0,37 & 0,51 & 0,79 & 1,00 & 0,44 \\
\hline ПАТ «Харвест» & 0,80 & 0,48 & 0,00 & 0,46 & 0,92 & 0,91 & 0,75 & 0,99 & 0,96 & 0,23 \\
\hline ПАТ «Дніпропетровсь & 0,21 & 0,19 & 0,15 & 0,12 & 0,23 & 0,20 & 0,03 & 0,03 & 0,26 & 0,10 \\
\hline ПрАТ Калинівське РП «Агромаш» & 0,74 & 0,70 & 0,85 & 0,76 & 0,96 & 0,32 & 0,14 & 0,67 & 0,61 & 0,50 \\
\hline ПрАТ «Барський машинобудівний завод» & 0,33 & 0,26 & 0,24 & 0,23 & 0,26 & 0,31 & 0,28 & 0,36 & 0,37 & 0,85 \\
\hline ПрАТ «Калинівський машинобудівний завод» & 0,10 & 0,14 & 0,19 & 0,39 & 0,32 & 0,25 & 0,21 & 0,47 & 0,30 & 0,60 \\
\hline $\begin{array}{l}\text { ПрАТ «Каховський експеримент } \\
\text { механічний завод» }\end{array}$ & 0,75 & 0,73 & 0,22 & 0,44 & 0,46 & 0,79 & 0,20 & 0,14 & 0,30 & 0,57 \\
\hline $\begin{array}{l}\text { ПрАТ «Могилів-Подільський машинобудівний } \\
\text { завод» }\end{array}$ & 0,16 & 0,24 & 0,36 & 0,28 & 0,72 & 0,57 & 0,59 & 0,48 & 0,19 & 0,19 \\
\hline ПрАТ «Хорольський механічний завод» & 0,99 & 0,99 & 0,90 & 0,95 & 0,95 & 0,95 & 0,95 & 0,86 & 0,97 & 0,96 \\
\hline ПАТ «Вібросепаратор» & 1,00 & 0,99 & 0,90 & 0,95 & 0,95 & 0,95 & 0,95 & 0,86 & 0,97 & 0,96 \\
\hline ПрАТ «Гребінківський м & 0,06 & 0,25 & 0,30 & 0,33 & 0,33 & 0,01 & 0,18 & 0,19 & 0,22 & 0,20 \\
\hline ПрАТ «Куп’янський машинобудівний завод» & 0,04 & 0,03 & 0,21 & 0,15 & 0,14 & 0,14 & 0,18 & 0,14 & 0,29 & 0,12 \\
\hline ПрАТ «Полтавський машинобудівний завод» & 0,39 & 0,35 & 0,31 & 0,29 & 0,13 & 0,15 & 0,12 & 0,15 & 0,16 & 0,07 \\
\hline ПрАТ «Бердянські жниварки» & 0,10 & 0,35 & 0,34 & 0,25 & 0,16 & 0,06 & 0,45 & 0,45 & 0,48 & 0,52 \\
\hline ПрАТ «Богуславська сільгоспт & 0,18 & 0,47 & 0,48 & 0,46 & 0,45 & 0,42 & 0,43 & 0,38 & 0,38 & 0,41 \\
\hline ПрАТ ВО «Восход» & 0,63 & 0,41 & 0,20 & 0,35 & 0,48 & 0,12 & 0,63 & 0,45 & 0,10 & 0,26 \\
\hline $\begin{array}{l}\text { ПАТ «Корсунь-Шевч } \\
\text { верстатобудівний зав }\end{array}$ & 0,40 & 0,89 & 0,93 & 0,18 & 0,91 & 0,82 & 0,59 & 0,58 & 0,61 & 0,02 \\
\hline \begin{tabular}{|l} 
ПрАТ «Ніжинськиі \\
сільськогосподарсь
\end{tabular} & 0,16 & 0,35 & 0,16 & 0,15 & 0,36 & 0,13 & 0,13 & 0,37 & 0,12 & 0,12 \\
\hline ПрАТ «Промінь» & 0,37 & 0,96 & 0,98 & 0,76 & 0,91 & 0,15 & 0,70 & 0,87 & 0,03 & 0,76 \\
\hline ПрАТ «Уманьферммаш» & 0,77 & 0,71 & 0,79 & 0,05 & 0,90 & 0,90 & 0,59 & 0,49 & 0,59 & 0,07 \\
\hline ПрАТ «Фрегат» & 0,62 & 0,96 & 0,94 & 0,14 & 0,98 & 0,96 & 0,38 & 0,75 & 0,88 & 0,07 \\
\hline ПАТ «Хмільниксільмаш» & 0,17 & 0,98 & 0,97 & 0,18 & 1,00 & 0,82 & 0,80 & 0,98 & 0,80 & 0,17 \\
\hline $\begin{array}{l}\text { ПАТ «Харківський тракторний завод } \\
\text { ім. С. Орджонікідзе» }\end{array}$ & 0,69 & 0,84 & 0,88 & 0,54 & 0,88 & 0,90 & 0,51 & 0,69 & 0,76 & 0,24 \\
\hline ПАТ «Ельворті» & 0,63 & 0,63 & 0,28 & 0,63 & 0,64 & 0,66 & 0,63 & 0,64 & 0,69 & 0,67 \\
\hline ПАТ «Кам’янець-Подільськсільмаш» & 0,79 & 0,79 & 0,80 & 0,80 & 0,12 & 0,15 & 0,20 & 0,58 & 0,59 & 0,55 \\
\hline ПАТ «Гідросила» & 0,10 & 0,32 & 0,71 & 0,36 & 0,54 & 0,36 & 0,40 & 0,35 & 0,50 & 0,51 \\
\hline
\end{tabular}

Значення фінансової складової конкурентного потенціалу підприсмств машинобудування 


\begin{tabular}{|c|c|c|c|c|c|c|c|c|c|}
\hline \multirow{2}{*}{$\begin{array}{c}\text { Стан } \\
\text { конкурентного } \\
\text { потенціалу } \\
\text { (за фінансовою } \\
\text { складовою) }\end{array}$} & \multicolumn{9}{|c|}{$\begin{array}{c}\text { Шкала значень узагальнюючого показника рівня формування та використання } \\
\text { фінансових ресурсів підприсмствами машинобудування* }\end{array}$} \\
\hline & $\begin{array}{c}\mathbf{0 , 0 0 1 -} \\
\mathbf{0 , 1 1 0}\end{array}$ & $\begin{array}{c}\mathbf{0 , 1 1 1}- \\
\mathbf{0 , 2 2 0}\end{array}$ & $\mathbf{0 , 2 2 1 -}$ & $\begin{array}{c}\mathbf{0 , 3 3 1 -} \\
\mathbf{0 , 4 5 0}\end{array}$ & $\begin{array}{c}0,451- \\
0,560\end{array}$ & $\begin{array}{c}0,561- \\
0,670\end{array}$ & $\begin{array}{c}0,671- \\
0,780\end{array}$ & $\begin{array}{c}0,781- \\
0,890\end{array}$ & $\begin{array}{c}0,891- \\
1,00\end{array}$ \\
\hline \multicolumn{10}{|l|}{ Критичний } \\
\hline \multicolumn{10}{|l|}{ Допустимий } \\
\hline \multicolumn{10}{|l|}{ Низький } \\
\hline \multicolumn{10}{|l|}{ Середній } \\
\hline Високий & & & & & & & & & \\
\hline
\end{tabular}

Рис. 1. Карта оцінювання стану конкурентного потенціалу (за фінансовою складовою)

* діапазон значень 0,001-0,110 визначає стан фінансових ресурсів як катастрофічний; 0,111-0,220 - як кризовий; $0,221-0,330$ є мінімальним значенням стану фінансових ресурсів для забезпечення фінансової стійкості; $0,331-0,450110$ визначає стан фінансових ресурсів як низький; 0,451-0,560 - як нижчий за середній; 0,561-0,670 - як середній; 0,671-0,780 - як вищий за середній; 0,781-0,890 - як достатній; 0,891-1,00 - як оптимальний

Джерело: розробка автора (з використанням формули Стерджеса)

Протягом аналізованого періоду значення узагальнюючого показника фінансової складової конкурентного потенціалу підприємств машинобудування, яке визначає стан фінансових ресурсів як катастрофічний $(0,00-0,11)$, мали такі підприємства: ПАТ «Дніпропетровський агрегатний завод» 2015 році; ПрАТ ВО «Восход», ПрАТ «Промінь» у 2016 році; ПрАТ «Харківпродмаш», ПАТ «Красилівський машинобудівний завод», ПрАТ «Полтавський машинобудівний завод», ПАТ «Корсунь-Шевченківський верстатобудівний завод ім. Б. Хмельницького», ПрАТ «Уманьферммаш» та ПрАТ «Фрегат» у 2017 році, що свідчить про катастрофічно низьку якість фінансової структури підприємства, зокрема відсутність виваженої структури капіталу, яка б відповідала вимогам підприємства та забезпечувала мінімальні фінансові ризики за умови досить високої ринкової вартості.

Протягом аналізованого періоду у кризовому стані за рівнем формування та використання фінансових ресурсів підприємств машинобудування $(0,11-0,22)$ перебували у 2015 році ПрАТ «Харківпродмаш» $(0,207)$, ПрАТ «Каховський експериментальний механічний завод» $(0,144)$, ПрАТ «Гребінківський машинобудівний завод» $(0,193)$, ПрАТ «Куп'янський машинобудівний завод» $(0,136)$, ПрАТ «Полтавський машинобудівний завод» (0,145); у 2016 році ПрАТ «Харківпродмаш» $(0,117)$, ПрАТ «Могилів-Подільський машинобудівний завод» $(0,190)$, ПрАТ «Гребінківський машинобудівний завод» $(0,218)$, ПрАТ «Полтавський машинобудівний завод» $(0,164)$, ПрАТ «Ніжинський завод сільськогосподарського машинобудування» $(0,118)$; у 2017 році ПрАТ «Могилів-Подільський машинобудівний завод» $(0,192)$, ПрАТ «Гребінківський машинобудівний завод» $(0,195)$, ПрАТ «Куп’янський машинобудівний завод» $(0,123)$, ПрАТ «Ніжинський завод сільськогосподарського машинобудування» $(0,117)$, ПАТ «Хмільниксільмаш» $(0,174)$, що обумовлене неспроможністю підприємств до забезпечення ефективної діяльності та нормалізації фінансового стану власними ресурсами i, відповідно, підвищення конкурентоспроможності. Крім того, має місце криза прибут- ковості, адже на підприємствах витрати перевищують доходи, спостерігаються втрата капіталу та криза ліквідності (підприємство не здатне за допомогою своїх активів погасити заборгованість), що приводить до високої фінансової залежності, втрати платоспроможності.

Значення узагальнюючого показника фінансової складової конкурентного потенціалу підприємств машинобудування, яке визначає стан фінансових ресурсів як мінімальний для забезпечення фінансової стійкості $(0,22-0,33)$ мали у 2015 році ПрАТ «Харківпродмаш» $(0,207)$, ПАТ «Красилівський машинобудівний завод» $(0,264)$; у 2016 році ПАТ «Красилівський машинобудівний завод $(0,326)$, ПАТ «Дніпропетровський агрегатний завод» $(0,260)$, ПрАТ «Калинівський машинобудівний завод» $(0,299)$, ПрАТ «Каховський експериментальний механічний завод» $(0,300)$, ПрАТ «Гребінківський машинобудівний завод» $(0,218)$, ПрАТ «Куп'янський машинобудівний завод» (0,287); у 2017 році ПАТ «Карлівський машинобудівний завод» (0,302), ПАТ «Харвест» (0,225), ПрАТ ВО «Восход» $(0,264)$, ПАТ «Харківський тракторний завод ім. С. Орджонікідзе» $(0,238)$, що свідчить про відсутність ефективної системи формування та використання фінансових ресурсів підприємства, а також зниження фінансової стійкості через великий обсяг капіталу, що приводить до підвищення ризику банкрутства, відповідно до чого кредитори змушені підвищувати рівень ставки відсотків за кредит з урахуванням додаткового фінансового ризику.

На низькому рівні формування та використання фінансових ресурсів підприємств машинобудування $(0,33-0,45)$ були у 2015 році ПАТ «Карлівський машинобудівний завод» (0,398), ПрАТ «Барський машинобудівний завод» $(0,358)$, ПрАТ ВО «Восход» $(0,450)$, ПрАТ «Ніжинський завод сільськогосподарського машинобудування» $(0,370)$, ПАТ «Гідросила (0,351); у 2016 році ПрАТ «Барський машинобудівний завод» (0,373), ПрАТ «Богуславська сільгосптехніка» (0,380); у 2017 році ПрАТ «Ремтехсільмаш» $(0,439)$, ПрАТ «Богуславська сільгосптехніка» $(0,414)$, що обумовлене перш за все низьким рівнем управління 
дебіторською заборгованістю, що приводить до вилучення коштів з обігу, виникнення витрат на управління дебіторською заборгованістю та ризику неповернення, втрат від інфляції та зниження прибутку. Крім того, невиправданий розмір дебіторської заборгованості $є$ іммобілізацією власного капіталу, а перевищення його певного рівня може привести до втрати ліквідності й навіть зупинки виробництва.

Значення узагальнюючого показника фінансової складової конкурентного потенціалу підприємств машинобудування, яке визначає стан фінансових ресурсів як нижчий за середній $(0,45-0,56)$ мали у 2015 році ПрАТ «Калинівський машинобудівний завод» $(0,473)$, ПрАТ «Могилів-Подільський машинобудівний завод» $(0,480)$, ПрАТ «Бердянські жниварки» $(0,452)$, ПрАТ ВО «Восход» $(0,450)$, ПрАТ «Уманьферммаш» (0,487); у 2016 році ПрАТ «Бердянські жниварки» $(0,477)$, ПАТ «Гідросила» $(0,501)$; у 2017 році ПрАТ Калинівське РП «Агромаш» $(0,496)$, ПрАТ «Бердянські жниварки» $(0,522)$, ПАТ «Кам'янець-Подільськсільмаш» $(0,551)$, ПАТ «Гідросила» $(0,514)$, що свідчить про те, що структура внутрішніх фінансових ресурсів цих підприємств не $є$ оптимальною, оскільки велику частку становлять амортизаційні відрахування, а незначну частку - фінансові ресурси, які формуються за рахунок прибутку. Крім того, у підприємств великий обсяг позикового капіталу, використання якого приводить до фінансових труднощів через обмеження термінів позики здебільшого кредитним договором та високою відсотковою ставкою.

На середньому рівні формування та використання фінансових ресурсів підприємств машинобудування $(0,56-0,67)$ перебували у 2015 році ПрАТ «Дніпрополімермаш» $(0,561)$, ПрАТ Калинівське РП «Агромаш» $(0,667)$, ПАТ «Корсунь-Шевченківський верстатобудівний завод ім. Б. Хмельницького» (0,576), ПАТ «Ельворті» $(0,644)$, ПАТ «Кам’янецьПодільськсільмаш» $(0,579)$, ПАТ «Карлівський машинобудівний завод» $(0,572)$, ПрАТ «Дніпрополімермаш» (0,561), ПрАТ Калинівське РП «Агромаш» $(0,607)$, ПАТ «Корсунь-Шевченківський верстатобудівний завод ім. Б. Хмельницького» $(0,608)$, ПрАТ «Уманьферммаш» (0,591), ПАТ «Кам'янець-Подільськсільмаш» (0,590); у 2017 році ПрАТ «Дніпрополімермаш» (0,571), ПрАТ «Каховський експериментальний механічний завод» $(0,566)$, що обумовлене недостатньою ефективністю акумулювання фінансових ресурсів, оскільки досліджувані підприємства здебільшого фінансуються за рахунок залучених коштів, наслідком чого $є$ неспроможність підприємств за рахунок власних джерел забезпечити ефективний розвиток і, відповідно, конкурентоспроможність. Невиправданий обсяг кредиторської заборгованості унеможливлює своєчасний розрахунок підприємствами за своїми зобов'язаннями, що негативно позначається на ліквідності підприємства загалом. Крім того, перевищення позикових коштів над власними свідчить про недостатній рівень фінансової стійкості підприємства та його залежність від зовнішніх джерел фінансування.
Значення узагальнюючого показника фінансової складової конкурентного потенціалу підприємств машинобудування, яке визначає стан фінансових ресурсів як вищий за середній $(0,67-0,78)$ мали у 2015 році ПрАТ Калинівське РП «Агромаш» $(0,667)$, ПрАТ «Фрегат» $(0,747)$, ПАТ «Харківський тракторний завод ім. С. Орджонікідзе» $(0,691)$; у 2016 році ПАТ «Харківський тракторний завод ім. С. Орджонікідзе» $(0,757)$, ПАТ «Ельворті» $(0,694) ;$ у 2017 році ПрАТ «Автоелектроапаратура» $(0,777)$, ПрАТ «Промінь» $(0,757)$, ПАТ «Ельворті» $(0,672)$ унаслідок недосконалої системи управління фінансовими ресурсами підприємства, оскільки короткострокові фінансові ресурси підприємств майже на $60 \%$ сформовані за рахунок кредиторської заборгованості за товари та послуги. Також на досить низькому рівні залишається фінансова активність підприємств з управління тимчасово вільними грошовими коштами, що приводить до неспроможності підприємств забезпечувати конкурентоспроможність.

Достатній рівень формування та використання фінансових ресурсів підприємств машинобудування $(0,78-0,89)$ мали у 2015 році ПрАТ «Автоелектроапаратура» $(0,787)$, ПрАТ «Ремтехсільмаш» $(0,785)$, ПрАТ «Хорольський механічний завод» $(0,860)$, ПАТ «Вібросепаратор» $(0,861)$, ПрАТ «Промінь» $(0,874)$; у 2016 році ПрАТ «Автоелектроапаратура» (0,872), ПрАТ «Фрегат» $(0,876)$, ПАТ «Хмільниксільмаш» (0,800); у 2017 році ПрАТ «Барський машинобудівний завод» $(0,854)$, що свідчить про достатній обсяг фінансових ресурсів у підприємств, а їхня структура дає змогу досягти планового рівня прибутковості, зміцнення фінансової стійкості, забезпечення достатнього рівня платоспроможності, зростання ринкової вартості та забезпечення конкурентоспроможності.

На оптимальному рівні формування та використання фінансових ресурсів підприємств машинобудування $(0,89-1,00)$ перебували у 2015 році ПАТ «Харвест» (0,990), ПАТ «Хмільниксільмаш» (0,984); у 2016 році ПрАТ «Ремтехсільмаш» $(0,998)$, ПАТ «Харвест» $(0,960)$, ПрАТ «Хорольський механічний завод» $(0,967)$, ПАТ «Вібросепаратор» $(0,965)$; у 2017 році ПрАТ «Хорольський механічний завод» $(0,964)$, ПАТ «Вібросепаратор» $(0,963)$, що підтверджує ефективність наявної на підприємствах системи формування, розподілу та використання фінансових ресурсів, яка спроможна забезпечити підтримку оптимальної структури і нарощування конкурентного потенціалу підприємства, забезпечення поточної економічної діяльності. Інакше кажучи, система управління фінансовими ресурсами цих підприємств дає змогу забезпечити стійкий фінансовий стан підприємства.

Висновки. Результати оцінювання фінансової складової конкурентного потенціалу підприємств машинобудування із застосуванням методу таксономії дали змогу визначити стан формування, акумулювання, забезпеченості та використання фінансових ресурсів, що дасть можливість підтримувати підприємства у бажаному конкурентному стані, формувати, утримувати та зміцнювати тривалі конкурентні переваги. Попри те, що представ- 
лена методика оцінювання фінансової складової конкурентного потенціалу підприємств машинобудування в системі економічного управління є універсальною (дає змогу оцінити конкурентний потенціал як загалом, так i в розрізі його складових), у подальшому вона може доповнюватись новими підходами, методами та відповідними моделями, зокрема, щодо врахування впливу факторів на забезпечення конкурентоспроможності підприємств машинобудування за рахунок здатності внутрішньої структури підприємства вчасно реагувати на зміни зовнішнього середовища, відслідковувати зміни у структурі потреб споживачів, розбіжності між вимогами ринку та можливостями підприємств загалом задля підвищення економічних результатів їхньої діяльності.

\section{Список літератури:}

1. Лігоненко Л.О. Концептуальні засади економічного управління підприємством. Вісник Київського національного торговельно-економічного університету. 2013. № 3. С. 5-17.

2. Плюта В. Сравнительный многомерный анализ в экономических исследованиях. Методы таксономии и факторного анализа. Москва : Статистика, 1980. 151 с.

References:

1. Lihonenko L. (2013). Kontseptualni zasady ekonomichnoho upravlinnia pidpryiemstvom [Conceptual foundations of economic management of an enterprise]. Visnyk Kyivskoho natsionalnoho torhovelno-ekonomichnoho universytetu, no. 3, pp. 5-17.

2. Pliuta V. (1980) Sravnytelny'i mnohomerny'i analyz $v$ e'konomycheskykh yssledovanyiakh. Metody' taksonomyy y faktornoho analyza. [Comparative multivariate analysis in economic research. Taxonomy and factor analysis methods]. Moscow : Statystyka, 151. (in Russian)

\section{МЕТОДИЧЕСКИЙ ПОДХОД К ОЦЕНИВАНИЮ ФИНАНСОВОЙ СОСТАВЛЯЮЩЕЙ КОНКУРЕНТНОГО ПОТЕНЦИАЛА ПРЕДПРИЯТИЙ МАШИНОСТРОЕНИЯ В СИСТЕМЕ ЭКОНОМИЧЕСКОГО УПРАВЛЕНИЯ}

В статье отражень основные этапы применения методического подхода к оцениванию финансовой составляющей конкурентного потенциила предприятий машиностроения в системе экономического управления. Оиенивание финансовой составляющей конкурентного потенциала осуществлено за 2008-2017 годы на основе данных финансовой отчетности тридцати одного предприятия машиностроения, которые по классификатору видов экономической деятельности отнесены к группе «Производство машин и оборудования, не отнесенных $\kappa$ другим категориям». Определены эталонные значения формирования и использования финансовых ресурсов предприятиями машиностроения за исследуемый период. Рассчитано расстояние от эталонного значения, осуществлено распределение предприятий машиностроения по обобщающелу показателю финансовой составляющей конкурентного потенциала по уровням на основе разработанной шкаль формирования и использования финансовых ресурсов. Предложенный методический подход позволит сравнить реальные и необходимье ресурсные возможности достижения экономических иелей и выполнения задний предприятия в конкурентной среде.

Ключевые слова: конкурентоспособность предприятия, конкурентный потенциал, конкурентные преимущества, экономическое управление предприятием, финансовые ресурсы, финансовая составляющая конкурентного потенциала, предприятия машиностроения.

\section{METHODICAL APPROACH TO THE ESTIMATION OF THE FINANCIAL COMPONENT OF COMPETITIVE POTENTIAL OF MACHINE BUILDING ENTERPRISES IN THE ECONOMIC MANAGEMENT SYSTEM}

It is established that the financial component of competitive potential reflects the availability of the enterprise capabilities, abilities, competitive strength in the formation and use of financial resources, their rational allocation and the right combination (taking into account the influence of external factors) and creates preconditions for increasing the competitiveness of the enterprise. The main stages of application of the methodical approach to the estimation of the financial component of competitive potential of machine-building enterprises in the system of economic management are explained in the article. The assessment of the financial component of competitive potential was made for the period 2008-2017 on the basis of the financial statements of thirty-one machine-building enterprises which according to the classifier of economic activities are classified in the group "Manufacture of machinery and equipment not elsewhere classified", that produce machinery and equipment for agriculture and forestry and for the production of food and beverages, tobacco processing. The method of taxonomic analysis, which avoids or a combination of several methods of 
modeling and therefore double counting of indicators that will increase the probability of the results, was used to evaluate the financial component of the competitive potential of machine-building enterprises. The method is based on a set of indicators characterizing the state of financial resources of machine-building enterprises. Reference values of formation and use of financial resources by machine-building enterprises for the studied period are determined. Distances from the reference value are calculated and the division of machine-building enterprises according to the aggregate indicator of the financial component of competitive potential according to the levels based on the developed scale of formation and use of financial resources is made. The proposed methodical approach will allow comparing real and necessary resource possibilities of achievement of economic goals and tasks of the enterprise in a competitive environment.

Key words: enterprise competitiveness, competitive potential, competitive advantages, economic management of an enterprise, financial resources, financial component of competitive potential, machine-building enterprises. 